\title{
USED OIL ANALYSIS FOR INTERNAL COMBUSTION ENGINE CONDITION MONITORING
}

\author{
Abdel Gadir Abdel Gabar ALLA Jabo \\ $\mathrm{PhD}$ Student \\ Faculty of post graduates Faculty of post graduates \\ Nile Valley University, Atbara, Sudan
}

\begin{abstract}
Engines are the main part of power plants.
\end{abstract} The performance of the engine depends upon the good condition of the components like cylinders, cylinder heads, pistons, piston rings, valves, and connecting rods, etc.

The failure of engine components can be reduced by using condition monitoring techniques. There are many types of condition monitoring techniques are available. The famous Non-destructive Tests (NDTs) for engines condition monitoring are including vibration analysis, infrared thermography, and engine used oil analysis.

The aim of this research is to reduce the failures of engine components by analyzing the used oil. Oil is the lifeblood of engines. Much like doctors assess human health through blood analysis, engine components can be monitored in much the same manner. Engine oil analysis means testing a sample of engine oil in unused or used condition. Analysis is done for various properties like Viscosity, Total Base Number (TBN), Total Acid Number (TAN), Ash Content, Flash Point, Water Content, Contamination, and Wear Metal particles which used to monitor the wear rate of engine components. The result of the analysis is then compared with the given analysis limits to assess the quality of lubricant and the possibility of further using, or not.

The properties of oil will be changed based on engine running hours. The used oil can be collected from engine after various running hours for analyzing, and the test result is used to assess the condition of engine and oil quality, then maintenance decision will be made according to those results. This optimization of maintenance activities will result in a reasonable cost reduction by increasing the interval of lubricant replacing and saving time and efforts of maintenance authorities.

Keywords - Condition monitoring, Used oil analysis, Viscosity, Total base number, Total acid number, Optimization.

\author{
Dr. Midhat Victor Eskandar \\ Department of Mechanical Engineering \\ Faculty of Engineering and Technology \\ Nile Valley University, Atbara, Sudan
}

\section{INTRODUCTION}

The definition of analysis can be expressed in many ways, it can be defined as a close examination of something in order to understand it better or draw conclusion from it. Another definition, it is the separation of something into its constituents in order to find out what it contains. It can be defined as to examine individual parts or to study the structure of the whole. Analyses can be an assessment, description or explanation of something usually based on careful consideration or investigation.

Used oil analysis is an important part of engine maintenance. It provides information about the condition of the oil, its suitability for further use, and to certain extends information about condition of the machinery lubricated by the oil. Precondition of a valuable oil analysis and its interpretation is a sample being taken according to a reliable procedure.

Two methods are used for oil analysis, routine methods and advanced methods. Routine methods are used in all engines oil analysis. The advanced methods are several and provide additional information. The laboratory oil analysis is a snap-shot of oil condition at the time the oil sample was taken. Filling the gap between oil sampling can be done with on-line monitoring or with on-site analysis using portable test kits.

Oil analysis techniques fall into the following three types. The first is concentration analysis of wear particles in lubricant. This can be conducted in the field or the laboratory. The second is wear debris analysis. This deals with examination of the shape, size, number, composition, and other characteristics of the wear particles so as to identify the wear state. This is usually conducted in the laboratory. The third is lubricant degradation analysis. This is used to analyze physical and chemical characteristics of lubricant and determine the state of lubricant. This can be conducted in the field or the laboratory.

The study of used oil analysis technique for Internal Combustion (IC) engine condition monitoring will be carried out at a Power Plant which is used as the main power supplier for an Oil Field. The plant consists eight dual fuel engines, 
ALLEN DIESEL 4012, with capacity of 3.5 MW for each engine. Diesel fuel oil is used for engine start up and flushing prior engine stoppage, while crude oil is used for continuous running. Crude oil is enhanced for engine consumption through separators and heating and pumping modules. The lubrication system is a self-contained wet sump lubricating oil system with a capacity of 10 drums (2000 liters) for both sump and filters. A motor driven lubricating oil priming pump, operates continuously during engine shutdown to allow immediate engine starting on mains failure.

\section{EXPERMENTAL WORK AND PROCEDURES}

Experimental work is carried out at lube oil supplier laboratory as an after sale service to assess oil quality during service and obtain the perfect time to replace the oil based on analysis result rather than a fixed time intervals.

Used oil characteristics are tested by the following test methods to assess oil quality and possibility for further usage, and to monitor engine components conditions;

\section{ASTM D 445, test method for Kinematic Viscosity at $40^{\circ} \mathrm{C}$} and $100^{\circ} \mathrm{C}$.

\section{1-1 Scope of Test Method:-}

This test method specifies a procedure for the determination of the kinematic viscosity of liquid petroleum product, by measuring the time for a volume of liquid to flow under gravity through a calibrated glass capillary viscometer. The range of kinematic viscosities covered this test method is from 0.2 to $300000 \mathrm{~mm} 2 / \mathrm{s}$ at all temperatures.

\section{1-2 Significance and Use:-}

Many petroleum products and some non-petroleum materials are used as lubricants and the correct operation of the equipment depends upon the appropriate viscosity of the being used. In addition, the viscosity of many petroleum fuels is important for the estimation of optimum storage, handling, and operational conditions. Thus the accurate determination of viscosity is essential to many product specifications.

\section{1-3 Summary of the Test Method:-}

The time measured for a fixed volume of liquid to flow under gravity through the capillary of a calibrated viscometer under a reproducible driving head and at a close controlled and known temperature. The kinematic viscosity (determined value) is the product of the measured flow time and the calibration constant of the viscometer. Two such determinations are needed from which to calculate a kinematic viscosity determined values.

2. ASTM D 2270, test method for Viscosity Index for Kinematic Viscosity at $40^{\circ} \mathrm{C}$ and $100^{\circ} \mathrm{C}$.

2-1 Scope of Test Method:-
This practice covers the procedure for calculating the viscosity index of petroleum products, such as lubricating oils, and related materials from the kinematic viscosities at $40^{\circ} \mathrm{C}$ and $100^{\circ} \mathrm{C}$.

\section{2-2 Significance and Use:-}

The viscosity index is a widely used and accepted measure of the variation in the kinematic viscosity due to change in in the temperature of a petroleum product between $40^{\circ} \mathrm{C}$ and $100^{\circ} \mathrm{C}$.

\section{2-3 Test Procedures:-}

2-3-1 Procedure A, Oils of Viscosity Index Up and Including 100:-

1. Determine the kinematic viscosity of the sample at $40^{\circ} \mathrm{C}$ and $100^{\circ} \mathrm{C}$.

2. If the kinematic viscosity of the oil at $100^{\circ} \mathrm{C}$ is less or equal to $70 \mathrm{~mm} 2 / \mathrm{s}$ (cSt), extract from the table of basic Values for $\mathrm{L}$ and $\mathrm{H}$ for Kinematic Viscosity in 40 to $100^{\circ} \mathrm{C}$ System, the corresponding values of $\mathrm{L}$ and $\mathrm{H}$, measured values that are not listed, but are within the range of basic values table, may obtained by linear interpolation.

3. If the kinematic viscosity at $100^{\circ} \mathrm{C}$ above $70 \mathrm{~mm} 2 / \mathrm{s}(\mathrm{cSt})$, calculate the values of $\mathrm{L}$ and $\mathrm{H}$ as follows;

$$
\begin{gathered}
\mathrm{L}=0.8353 \mathrm{Y} 2+14.67 \mathrm{Y}-216 \\
\mathrm{H}=0.1684 \mathrm{Y} 2+11.85 \mathrm{Y}-97
\end{gathered}
$$

Where;

$\mathrm{L}=$ kinematic viscosity at $40^{\circ} \mathrm{C}$ of an oil of viscosity index having the kinematic viscosity at $100^{\circ} \mathrm{C}$ as the oil whose viscosity index to be calculated, $\mathrm{mm} 2 / \mathrm{s}(\mathrm{cSt})$.

$\mathrm{Y}=$ kinematic viscosity at $100^{\circ} \mathrm{C}$ of the oil whose viscosity index to be calculated, $\mathrm{mm} 2 / \mathrm{s}(\mathrm{cSt})$.

$\mathrm{H}=$ kinematic viscosity at $40^{\circ} \mathrm{C}$ of an oil of 100 viscosity index having the same kinematic viscosity at $100^{\circ} \mathrm{C}$ as the oil whose viscosity index is to be calculated, $\mathrm{mm} 2 / \mathrm{s}(\mathrm{cSt})$.

4. Calculate the viscosity index, VI, of the oil as follows;

Where;

$$
\mathrm{VI}=[(\mathrm{L}-\mathrm{U}) /(\mathrm{L}-\mathrm{H})] \times 100
$$

$\mathrm{U}=$ kinematic viscosity at $40^{\circ} \mathrm{C}$ of the oil whose viscosity index is to be calculated, $\mathrm{mm} 2 / \mathrm{s}(\mathrm{cSt})$.

- A high viscosity index indicates a smaller decrease in kinematic viscosity with increasing temperatures of the lubricant.

- The viscosity index is used in practice as a single number indicating temperature dependence of kinematic viscosity.

\section{2-3-2 Procedure B, Oils of Viscosity Index of 100 and} Greater:-

1. Determine the kinematic viscosity of the sample at $40^{\circ} \mathrm{C}$ and $100^{\circ} \mathrm{C}$.

2. If the kinematic viscosity of the oil at $100^{\circ} \mathrm{C}$ is in the range of 2 to $70 \mathrm{~mm} 2 / \mathrm{s}(\mathrm{cSt}$ ), extract the corresponding value for $\mathrm{H}$ from the table of basic Values for $\mathrm{L}$ and $\mathrm{H}$ for Kinematic Viscosity in 40 to $100^{\circ} \mathrm{C}$ System, measured values that are not 
listed, but are within the range of the table, may obtained by linear interpolation.

3. If the measured kinematic viscosity at $100^{\circ} \mathrm{C}$ is greater than $70 \mathrm{~mm} 2 / \mathrm{s}$ (cSt), calculate the value of $\mathrm{H}$ as follows;

$$
\mathrm{H}=0.1684 \mathrm{Y} 2+11.85 \mathrm{Y}-97
$$

Where;

$\mathrm{Y}=$ kinematic viscosity at $100^{\circ} \mathrm{C}$ of the oil whose kinematic viscosity is to be calculated, $\mathrm{mm} 2 / \mathrm{s}(\mathrm{cSt})$.

$\mathrm{H}=$ kinematic viscosity at $40^{\circ} \mathrm{C}$ of an oil of 100 viscosity index having the same kinematic viscosity at $100^{\circ} \mathrm{C}$ as the oil whose viscosity index to be calculated , $\mathrm{mm} 2 / \mathrm{s}(\mathrm{cSt})$.

4. Calculate the viscosity index, VI, of the oil as follows;

$$
\mathrm{VI}=[((\operatorname{antilog} \mathrm{N})-1) / 0.00715]+100
$$

Where;

$$
\begin{gathered}
\mathrm{N}=(\log \mathrm{H}-\log \mathrm{U}) / \log \mathrm{Y} \\
\mathrm{Or} \\
\mathrm{Y} \mathrm{N}=\mathrm{H} / \mathrm{U}
\end{gathered}
$$

Where;

$\mathrm{U}=$ kinematic viscosity at $40^{\circ} \mathrm{C}$ of the oil whose viscosity index is to be calculated, $\mathrm{mm} 2 / \mathrm{s}(\mathrm{cSt})$.

\section{ASTM D2896, test method for Total Base Number TBN.}

\section{3-1 Scope of Test Method:-}

This test method covers the determination of basic constituent in petroleum products by titration with perchloric acid in glacial acetic acid.

\section{3-2 Significance and Use:-}

New and used petroleum products can contain basic constituents that are present as additives. The relative amounts of these materials can be determined by titration with acids. The base number is a measure of the amount of the basic substance in the oil, always under the conditions of the test it is sometimes used as a measure of lubricant degradation in service, however, any condemning limits must be empirically established.

\section{3-3 Summary of the Test Method:-}

The sample is dissolved in an essentially anhydrous mixture of chlorobenzene glacial acetic acid and titrated with a solution of perchloric acid in glacial acetic acid using potentiometer titrimeter. A glass indicating electrode and a reference electrode are used, the latter being connected with the sample solution by means of a salt bridge. The meter readings are plotted against the respective volumes of titrating solution, and the end point is taken at the inflection in resulting curve.

4. ASTM E2412, test method for Condition Monitoring by Trend Analysis Using Fourier Transform Infrared (FT- IR) Spectrometery

4-1 Scope of Test Method:-
This practice covers the use of FT-IR in monitoring additive depletion, contaminant build up and base stock degradation in machinery lubricants, hydraulic fluids, and other fluids used in normal machinery operation. Contaminants monitored include water, soot, ethylene glycol, fuels, and incorrect oil. Oxidization, nitration, and sulfonation of base stocks are monitored as evidence of degradation. The objective of this monitoring activity is to diagnose the operational condition of the machines based on fault conditions observed in the oil. Measurement and data interpretation parameters are presented to allow operators of different FT-IR spectrometers to compare results by employing the same techniques.

\section{4-2 Significance and Use:-}

Periodic sampling and analysis of lubricants have long been used as a means to determine overall machinery health. Atomic Emission (AE) and Atomic Absorption (AA) spectroscopy are often employed for wear metal analysis. A number of physical property tests complement wear metal analysis and are used to provide information on lubricant condition. Molecular analysis of lubricants and hydraulic fluids by FT-IR spectroscopy produces direct information on molecular species of interest, including additives, fluid breakdown products and external contaminants, and thus complements wear metal and other analysis used in a condition monitoring program.

\section{4-3 Summary of Test Method:-}

Periodic samples are acquired from the engine of machine being monitored. An infrared absorbance spectrum of the sample is acquired, typically covering the range of 4000 to $550 \mathrm{~cm}-1$, with sufficient signals-to- noise $(\mathrm{S} / \mathrm{N})$ ratio to measure absorbance areas of interest. Exact data acquisition parameters will vary depending on instrument manufacturer but most systems should be able to collect an absorbance adequate to for most measurement in less than one minute. Features in the infrared spectrum indicative of the molecular level component of interest (that is water, fuel, antifreeze, additive, degradation and so forth) are measured and reported. Condition alerts and alarms can be then triggered according to both the level and the trends from the monitored system.

\section{ASTM D4951, test method for Metallic Particles.}

\section{5-1 Scope of Test Method:-}

This method covers the quantitative determination of barium, boron, calcium, copper, magnesium, molybdenum, phosphorous, sulfur, and Zink in unused and used lubricating oils and additive package.

\section{5-2 Significance and Use:-}

This test method usually requires several minutes per sample. This test covers more than eight elements and thus provides more elemental composition data. 


\section{International Journal of Engineering Applied Sciences and Technology, 2021 \\ Vol. 5, Issue 9, ISSN No. 2455-2143, Pages 10-16 \\ Published Online January 2021 in IJEAST (http://www.ijeast.com)}

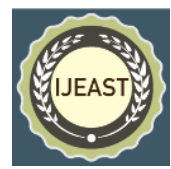

Additive packages are blends of individual additives, which can act as detergents, anti oxidant, anti wear agents, and so forth. Many additives contain one or more elements covered by this test method. Additive packages specifications are based, in part, on elemental composition. Lubricating oils are typically blends of additives packages, and their specifications are also determined, in part, by elements composition. This test method can be used to determine if additive packages and unused lubricating oils meet specification with respect to elemental composition.

\section{5-3 Summary of Test Method:-}

A sample portion is weighted and diluted by mass with mixed xylene or other solvent. An internal standard, which is required, either weighted separately into the test solution or is previously combined with the dilution solvent. Calibration standards are prepared similarly. The solutions are introduced to the Inductively Coupled Plasma, ICP instrument by free aspiration or an optional peristaltic pump. By comparing emission intensities of elements in the test specimen with emission intensities measured with the calibration standards and by applying the appropriate internal standard correction, the concentrations of elements in the sample are calculated.

\section{Crackle Test for Water Content.}

\section{6-1 Scope of Test Method:-}

This test is intended to determine whether or not there is water in lubrication oil.

\section{6-2 Scope of Test Method:-}

The crackle test is a simple test to determine whether or not there is water in lubrication oil. The crackle test can be performed in the field using a hot plate. The test is mostly qualitative. It tells you whether there is water present.

\section{6-3 Significance and Use:-}

Careful observation of the oil on the hot plate can gives some semi qualitative information about the amount of water present, but it is vary dependent on the skill of the operator.

\section{6-4 Summary of Test Method:-}

The crackle test requires a temperature controlled hot plate. Typically the hot plate temperature is set to approximately $160^{\circ} \mathrm{C}$. Ideally, the sample is mixed by vigorous shaking. This creates a more homogenous suspension of water in oil. Once the sample is prepared, a drop of oil is placed onto the hot plate and observed.

If there is no water in the oil, no crackling will be observed. Conversely, if the oil does contain liquid water, the heat will cause it to change to vapor stage creating observable bubbles in the oil droplet. The size of the bubbles roughly corresponds to the amount of water present in the oil, the large the bubble, the more water there is dissolved in the oil. By observing the size of the bubble created in the hot plate, some quantitative judgments can be made about the concentration of water present in the oil sample.

\section{RESULTS AND DISCUSSION}

\section{1- Data Collection Duration:-}

Samples of used oil analysis for this study were collected in the period from November 2018 to December 2019 based on engines operation schedule and overhaul plans. The intervals of samples collection were about four weeks or 500 running hours.

\section{2- Data Analysis:-}

Used oil samples after collection and packing according to sample collection procedure, are sent for analyzing. Analysis is carried out at oil supplier laboratory. Used oil samples are subjected to many tests which considered previously to assess used oil quality for more usage, and to monitor the condition of engine internal parts for any kinds of wear.

\section{3- Categories of Analysis Results and Its Recommendations:-}

1- Oil and Equipment Conditions Are Satisfactory:-

Recommended to continue in usage.

2- Oil Viscosity is Increased:-

Recommended to replace lube oil and oil filters.

3- Oil Viscosity is Increased, But Still within the Limits:-

Recommended to send a sample after 250/500 running hours.

4- High Increase in Oil Viscosity Due to High Soot Content:-

Recommended to replace lube oil and oil filters, and to adjust air and fuel systems, and to send an oil sample after 500 running hours.

\section{4- Results of Data Analysis and Discussion:-}

During the period of this study, the numbers of sent used oil samples for each engine was varying between 7 to 11 samples based on engines operation schedule and engines overhaul plans. The following results are found during the study, and showed some benefits of carrying out these activities;

- Five engines (out of eight) were successfully exceeded the targeted 5000 running hours with the normal oil topping up.

- Two engines were subjected to oil replacement as per analysis result recommendation due to increased viscosity.

- Two engines were subjected to lube oil replacement to some engine parts failure, which led to lube oil contamination and thus oil viscosity increased.

- One engine is subjected to lube oil replacement before reaching the targeted running hours due to overhaul plan.

- Three engines were subjected to lube oil replacement according to increased viscosity as per analysis result, but no reason found for this increment.

- No any potential failure detected by using used oil analysis for condition monitoring and the metallic particles are within 
International Journal of Engineering Applied Sciences and Technology, 2021

Vol. 5, Issue 9, ISSN No. 2455-2143, Pages 10-16

Published Online January 2021 in IJEAST (http://www.ijeast.com)

\begin{tabular}{|c|c|c|c|c|c|c|}
\hline Engine & Sample Date & $\begin{array}{c}\text { Engine } \\
\text { Running } \\
\text { Hours }\end{array}$ & $\begin{array}{c}\text { Sample } \\
\text { Running } \\
\text { Hours }\end{array}$ & $\begin{array}{l}\text { Viscosity } \\
@ 40{ }^{\circ} \mathrm{C} \text { cSt }\end{array}$ & $\begin{array}{l}\text { Viscosity } \\
@ 100{ }^{\circ} \mathrm{C} \mathrm{cSt}\end{array}$ & Interpretation of Results \\
\hline B & $1 / 4 / 2019$ & 65,334 & 5,677 & 199.00 & 18.41 & $\begin{array}{l}\text { Oil \& Equipment conditions } \\
\text { are satisfactory }\end{array}$ \\
\hline $\mathrm{C}$ & $18 / 7 / 2019$ & 78,493 & 5,929 & 190.20 & 17.57 & $\begin{array}{l}\text { Oil \& Equipment conditions } \\
\text { are satisfactory }\end{array}$ \\
\hline $\mathrm{D}$ & $7 / 12 / 2018$ & 73,919 & 5,737 & 189.00 & 18.01 & $\begin{array}{l}\text { Oil \& Equipment conditions } \\
\text { are satisfactory }\end{array}$ \\
\hline $\mathrm{E}$ & $7 / 12 / 2018$ & 62,698 & 2,105 & 200.90 & 18.68 & $\begin{array}{l}\text { Oil viscosity is increased. } \\
\text { Please change the oil. }\end{array}$ \\
\hline $\mathrm{F}$ & $18 / 8 / 2019$ & 75,938 & 5,196 & 203.10 & 18.35 & $\begin{array}{l}\text { Oil \& Equipment conditions } \\
\text { are satisfactory }\end{array}$ \\
\hline $\mathrm{F}$ & $3 / 10 / 2019$ & 77,067 & 5,822 & 197.20 & 18.37 & $\begin{array}{l}\text { Oil \& Equipment conditions } \\
\text { are satisfactory }\end{array}$ \\
\hline $\mathrm{H}$ & $7 / 2 / 2019$ & 20,340 & 2,092 & 200.20 & 18.59 & $\begin{array}{l}\text { Oil viscosity is increased but } \\
\text { still within the limit. Please } \\
\text { send a sample after } 500 \mathrm{RH}\end{array}$ \\
\hline $\mathrm{H}$ & $28 / 2 / 2019$ & 20,797 & 2,461 & 203.10 & 19.08 & $\begin{array}{l}\text { Oil viscosity is increased. } \\
\text { Please change the oil }\end{array}$ \\
\hline $\mathrm{H}$ & $14 / 11 / 2019$ & 26,319 & 5,039 & 194.90 & 18.18 & $\begin{array}{l}\text { Oil \& Equipment Conditions } \\
\text { are Satisfactory }\end{array}$ \\
\hline
\end{tabular}

the lube oil manufacturer limits, which indicate to the healthiness of engine internal parts.

Table-01 Lube Oil Analysis Interpretation of Viscosity Results with Remarkable Recommendations 
International Journal of Engineering Applied Sciences and Technology, 2021

Vol. 5, Issue 9, ISSN No. 2455-2143, Pages 10-16

Published Online January 2021 in IJEAST (http://www.ijeast.com)

\begin{tabular}{|c|c|c|c|c|c|c|c|}
\hline Property & Fresh Sample & \multicolumn{2}{|c|}{ Warning } & \multicolumn{2}{|c|}{ Condemning } & Unit & Test Method \\
\hline $\begin{array}{c}\text { Kinematic Viscosity } \\
\text { at } 40^{\circ} \mathrm{C}\end{array}$ & 156 & 135.7 & 179.4 & 100.0 & 220.0 & $\mathrm{cSt}$ & ASTM D-445 \\
\hline $\begin{array}{c}\text { Kinematic Viscosity } \\
\text { at } 100^{\circ} \mathrm{C}\end{array}$ & 15.4 & 13.4 & 17.7 & 11.0 & 19.0 & $\mathrm{cSt}$ & ASTM D-445 \\
\hline Flash Point & 246 & & & \multicolumn{2}{|c|}{185.0} & ${ }^{\circ} \mathrm{C}$ & ASTM D-92 \\
\hline $\begin{array}{l}\text { Total Base Number } \\
\text { (TBN) }\end{array}$ & 12 & \multicolumn{2}{|c|}{9} & \multicolumn{2}{|c|}{6} & $\mathrm{mgKOH} / \mathrm{gm}$ & ASTM D-2896 \\
\hline Water content & - & & & \multicolumn{2}{|c|}{$+\mathrm{Ve}$} & - & Crackle \\
\hline $\mathrm{Fe}$ & - & 5 & 10 & above 10 & 5 & ppm & ASTM D-4951 \\
\hline $\mathrm{Si}$ & - & 5 & 10 & above 10 & 5 & $\mathrm{ppm}$ & ASTM D-4951 \\
\hline $\mathrm{Pb}$ & - & 25 & 50 & $\begin{array}{c}\text { above } \\
510\end{array}$ & 25 & ppm & ASTM D-4951 \\
\hline $\mathrm{Al}$ & - & 5 & 10 & above 10 & 5 & ppm & ASTM D-4951 \\
\hline
\end{tabular}

Table-02 Lube Oil Manufacturers’ Analysis Limits Guide Lines.

Details:

Equipment: Allen 4012

Fuel Type: Crude Oil

Lubricant type: PSW 12 SAE 40

Oil Pan Capacity: 1600L

Sampling Interval:500R/H 


\section{International Journal of Engineering Applied Sciences and Technology, 2021 \\ Vol. 5, Issue 9, ISSN No. 2455-2143, Pages 10-16 \\ Published Online January 2021 in IJEAST (http://www.ijeast.com)}

\section{CONCLUSION}

The interpretation of the study results of used lube oil analysis, conclude that the good management of lubricant is extending the intervals of oil replacement to more than the targeted five thousands running hours with the normal lube oil topping up, by a close monitoring for lubricant quality.

The study shows lubricating oil has less contamination and has a low concentration of metallic particle which indicates a good oil quality. This shows the good health condition of engines and less potential failure of components.

The study shows that reliability of engines is increased, because the potential failures are detectable and could be avoidable.

The contribution of used oil analysis technique is well determined by the study through cost cutting by extending oil replacement interval and reducing the number of services and its consequence costs.

\section{FURTHER WORK}

The study implicates the need to;

- Avail On-Site analysis kits for a quick test for immediate recommendation.

- Install on line test devices for a continuous testing and condition monitoring to fill the gap between oil sampling.

- Build Structured Query Language (SQL) data base to capture all engines lube oil test results for predictive maintenance utilization.

\section{REFERENCES}

[1] Synlube. (2019), Truth about Used Oil Analysis- a publication paper. MIROX CORPORATION.

[2] The International Council on Combustion Engines. (2011). Used Engine Oil Analysis - a User Interpretation Guide, number 30.CIMAC, (pp.3).

[3] Neale.M.J, Woodley. B. J. (1975). Condition Monitoring Methods and Economics, a paper presented at the symposium of the society of Environmental Engineers held at Imperial College. London September 1975.

[4] S. Gowtham. (2016). Condition Monitoring of I.C Engine by Using Oil Analysis. IJIRST Vol.2, issue 12, ISSN: 25496010, (pp.370-374).

[5] Dr. Tiwari Ashesh, Dubey Prakash Satya. (2017). Analysis of Wear Rate of Internal Combustion Engine using Ferrography Technique. IRJET Vol.04, issue 06, ISSN: 23950056, (pp.2212-2220).

[6] Yadv Gautam. (2014). Condition Monitoring of Internal Combustion Engine Using Oil Analysis Program. IJRMET Vol.4, issue 2, ISSN: 2249-5762, (pp.73-75).

[7] American Bureau of Shipping, ABS. (2016). Equipment Condition Monitoring Techniques, a guidance notes. (pp. 1-8, 15-18, 44-46, 90-92).
[8] Stanciu Ioana. (2012). Methods for Calculating the Viscosity Index Hydraulic Oil. Journal of Science and Arts Year 12, No.2 (19), ISSN: 1844-9581. (pp.177-180).

[9] Sharma Pankaja, Jayaswal Pratesh. (2012). Wear Rate Measurement (IC Engine) using Lubricant Oil Testing Method. IJREAS Vol.2, issue 7, ISSN: 2249-3905. (pp.21-37). [10] American Society for Testing and Materials Standards. (2006). Designation: D 445-6, Standard Test Method for Kinematic Viscosity of Transparent and Opaque Liquids (and Calculation of Dynamic Viscosity).

[11] American Society for Testing and Materials Standards. (2004). Designation: D 2270-04, Standard Practice for Calculating Viscosity Index from Kinematic Viscosity at 40 and $100^{\circ} \mathrm{C}$.

[12] American Society for Testing and Materials Standards. (2015). Designation: D 2896-15, Standard Test Method for Base Number of Petroleum Product by Potentiometric Perchloric Acid Titration.

[13] American Society for Testing and Materials Standards. (2010). Designation: E 2412-10, Standard Practice for Condition Monitoring of In-Service Lubricant by Trend Analysis Using Fourier Transform Infrared (FT-IR) Spectrometry.

[14] American Society for Testing and Materials Standards. (2014). Designation: D 4951-14, Standard Test Method for Determination of Additives Elements in Lubricating Oils by Inductively Coupled Plasma Atomic Emission Spectrometry.

[15] Spectro Scientific, White Paper. (2017). Guide to Measuring Water in Oil, white paper. (pp. 3). 